\title{
Pulmonary disease from occupational exposure to an artificial aluminium silicate used for cat litter
}

\author{
A W MUSK, H W GREVILLE, AND A E TRIBE \\ From the Departments of Respiratory Medicine and Pulmonary Physiology, Queen Elizabeth II Medical \\ Centre, Nedlands, Western Australia 6009
}

\begin{abstract}
All available workers engaged in bagging an artificial crystalline aluminium silicatethe kiln-dried residue from the calcining and water extraction of alunite (a hydrated sulphate of aluminium and potassium) that is currently classified as a nuisance dust-were studied after a complaint of respiratory and systemic symptoms, including arthritis, by an employee of the factory, who showed physiological and radiographic evidence of diffuse pulmonary fibrosis and in whom lung biopsy showed diffuse fibrosis with granulomas. Inhalation challenge produced a transient decrease in transfer factor and transfer factor standardised for alveolar volume. Twenty-five subjects were known to have been exposed at some time to the dust of alunite-residue. Of the 17 who could be contacted, all agreed to attend for respiratory questionnaire and occupational history, pulmonary function testing (spirometry, lung volumes, gas transfer), and posteroanterior chest radiograph. Six subjects considered that occupational exposure to the dust was responsible for respiratory symptoms. Three subjects had abnormality of the chest radiograph consistent with pulmonary fibrosis. The mean percentage of predicted transfer factor standardised for effective alveolar volume was $71 \cdot 1 \%$ in subjects with abnormal chest radiographs and $86.6 \%$ in subjects with normal radiographs $(\mathrm{p}=$ $0 \cdot 10)$. There was a trend in the correlation between the percentage of predicted transfer factor standardised for effective alveolar volume and total dust exposure (sum of the products of grade of severity of each exposure period and duration of each exposure period in months) $(\mathrm{r}=0.40 \mathrm{p}=$ $0 \cdot 10$ ). This study suggests that there may be a relation between inhalation of the dust of this form of aluminium silicate and pulmonary fibrosis.
\end{abstract}

Although pulmonary fibrosis has been described from occupational exposure to dusts of aluminium powder ${ }^{1}$ and aluminium oxide, ${ }^{2}$ and asthma has been associated with the smelting of aluminium, ${ }^{3}$ there is no record of pulmonary disease in man resulting from exposure to other compounds containing aluminium, although sillimanite, an aluminium silicate, may cause diffuse and nodular pulmonary fibrosis in rabbits. ${ }^{4}$ An artificial silicate of aluminium has been reclaimed from a dump in rural Western Australia since 1975. The dump of about 100000 tons was created during World War II when alunite clay from a salt lake was collected for the extraction

Received 10 May 1979

Accepted 17 October 1979 of potash. Alunite, a hydrated sulphate of aluminium and potassium, was calcined and then leached to yield potash $\left(\mathrm{K}_{2} \mathrm{SO}_{4}\right)$. The residue was dumped in a pile on the shores of the lake. This material, when dried to a water content of $2-3 \%$, has been found to be highly absorbent, and since 1975 it has been reclaimed, dried, and packaged for retail as cat litter. Analysis of this alunite-residue has shown it to consist predominantly of crystalline aluminium silicate (mullite) with no fibrous content (table 1). It has been classified as a "nuisance dust" in industry with permissible occupational exposures up to $10 \mathrm{mg} / \mathrm{m}^{3} \cdot{ }^{5-7}$

This study was undertaken because an employee of the firm engaged in packing the dried aluniteresidue complained of respiratory symptoms related to dust exposure. 
Table 1 Chemical analysis of alunite-residue*

\begin{tabular}{lc}
\hline Constituent & Percentage of dry weight \\
\hline Water soluble & \\
$\mathrm{K}_{2} \mathrm{SO}_{4}$ & $2 \cdot 0$ \\
$\mathrm{Na}_{2} \mathrm{SO}_{4}$ & $2 \cdot 5$ \\
$\mathrm{Mg} \mathrm{SO}_{4}$ & $3 \cdot 0$ \\
$\mathrm{Water}_{4}$ insoluble & $48 \cdot 5$ \\
$\mathrm{Al}_{2} \mathrm{O}_{3}$ & $35 \cdot 0$ \\
$\mathrm{SiO}_{2}$ (as silicate) & $5 \cdot 0$ \\
$\mathrm{Fe}_{2} \mathrm{O}_{3}$ & $4 \cdot 0$ \\
$\mathrm{~K}_{2} \mathrm{O}$ & $-100 \cdot 0$ \\
& 100
\end{tabular}

*Western Australian Government Chemical Laboratory.

\section{Subjects}

All 11 production staff who had ever worked for more than three months with the firm were studied. Of the 14 production staff who had worked for the firm for less than three months, six were traced and all participated. The study group therefore comprised 4 women and 13 men aged 15 to 52 years.

\section{Methods}

RESPIRATORY QUESTIONNAIRE

The British Medical Research Council Questionnaire on Smoking and Respiratory Symptoms was used to provide smoking category and scores for dyspnoea, cough, and phlegm. ${ }^{9}$ In addition the subjects were asked: "Do you think that work with 'kitty litter' affected your chest?" and "Have you ever had any joint troubles or arthritis?"

\section{EXPOSURE HISTORY}

Dried alunite-residue from the reclaiming site is stored in large bins at the outlet of which are automatic weighing machines and filling chutes. Bags are held under the chutes by an operator and filled with a preset weight of material at a rate of $30-40$ bags every minute. A second worker stands opposite the filling operator and removes the bags on to a conveyor belt where they are closed with a sewing machine and packed on to pallets for transport.

Dust exposure has not been quantitatively measured in the plant. When production started in 1975 there was no ventilation on the bagging machine. Complaints of the amount of dust in the work place led to the provision of a domestic fan to blow it away from the operator but subsequently exhaust ventilation was installed and appeared effective.

A complete occupational history was obtained for each subject. Exposure to the dust of alunite-residue during periods of employment was graded light $(=1)$, moderate $(=2)$, or heavy $(=3)$ on the detailed information obtained from each subject about his job assignment and the knowledge of the bagging process. Subjects working on the semiautomatic bagging machine before the installation of exhaust ventilation were considered heavily exposed. Subjects employed on the bagging machine since the installation of exhaust ventilation were considered moderately exposed, and those employed on stacking and moving the filled and closed bags within the factory were considered lightly exposed. Subjects working in the open reclaiming the clay from the lakeside dump were considered lightly exposed. Total exposure (the sum of the products of grade of severity of each exposure period and duration of each exposure period in months) was calculated for each subject.

\section{CHEST RADIOGRAPHS}

Standard posteroanterior chest radiographs were taken with the tube-object distance of $6 \mathrm{ft}(1.82 \mathrm{~m})$. The usual procedure required $150 \mathrm{kv}$, for $6-10 \mathrm{~m} \mathrm{sec}$ using a falling load tube current with ionisation chamber automatic exposure (Siemen's Iontomat) and a chest Buckey.

\section{PULMONARY FUNCTION}

The forced expiratory volume in one second $\left(\mathrm{FEV}_{1}\right)$ and forced vital capacity (FVC) were obtained from a digital spirometer (Hewlet-Packard, Burlington, Massachusetts). Transfer factor for carbon monoxide (TL) was measured by the single breath carbon monoxide method as modified by Ogilvie et al ${ }^{10}$ using a Resparameter (PK Morgan). Effective alveolar volume $\left(V_{A}\right)$ was estimated from the dilution of helium during the measurement of $T_{L}$. Each estimate was the mean of two measurements that differed by less than $10 \%$. The subdivisions of total lung capacity (TLC), vital capacity (VC), and residual volume (RV) were measured in a "flow" plethysmograph $^{11}$ (JG Emerson, Cambridge, Massachusetts) by the method of Dubois et al. ${ }^{12}$ The lung volumetranspulmonary pressure relationship of the employee presenting with respiratory symptoms was measured by the method of Milic Emili et al. ${ }^{13}$ Pulmonary compliance $(\mathrm{CL})$ was taken as the slope of the curve over the litre above functional residual capacity. Maximum transpulmonary pressure ( $P_{L}$ max) was the mean of the two highest recorded measurements at sustained maximum inspiration.

\section{ANTHROPOMETRIC MEASUREMENTS}

Height in stockinged feet was measured using a stadiometer.

STATISTICAL ANALYSIS

Because of the small population the pulmonary 


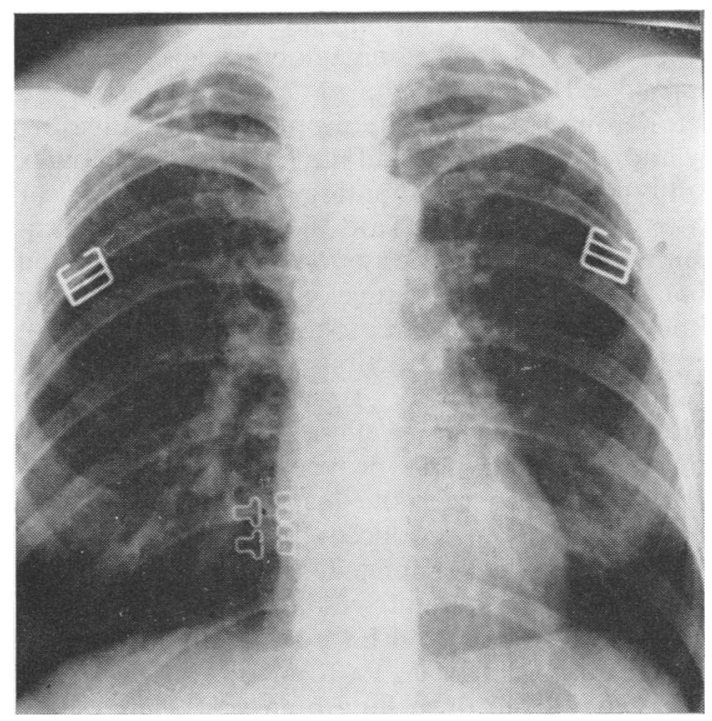

Fig 1 Posteroanterior chest radiograph taken August 1976 three months after onset of symptoms showing no definite abnormality.

function results were standardised for age, height, and sex by expressing them as a percentage of predicted normal value. FEV 1 and FVC were predicted from the regressions of Cherniack and Raber. ${ }^{14}$

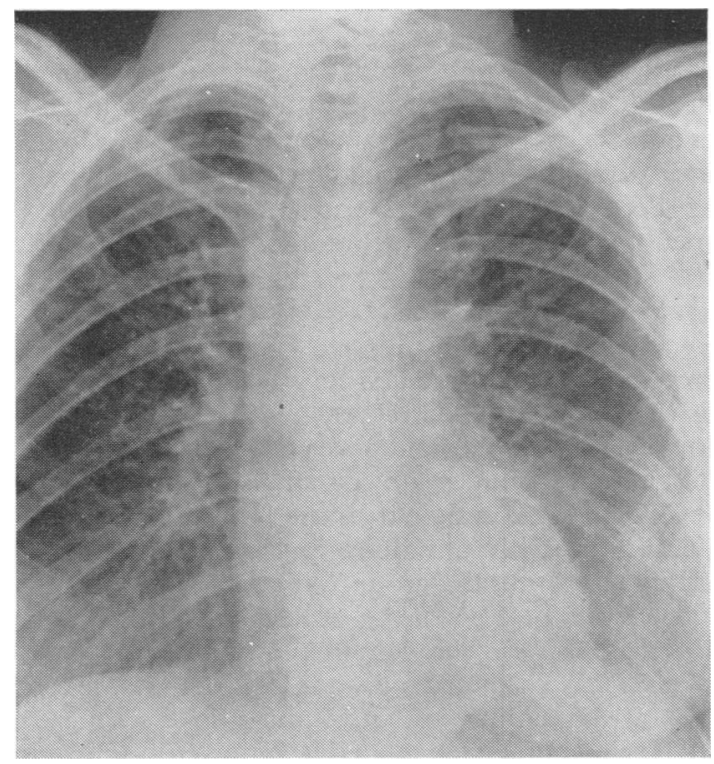

Fig 2 Posteroanterior chest radiograph taken March 1977 at presentation showing abnormal small irregular opacities throughout both lung fields.
TLC, RV, TL, and VA were predicted from Cotes..$^{15}$ PL max and $C_{L}$ were predicted from $\mathrm{H} J$ H Colebatch (personal communication).

\section{CASE REPORT}

This 42-year-old woman had never smoked cigarettes, had no history of previous hazardous exposure, and was well until the onset of her current illness. She was employed on the semi-automatic packaging machine filling bags with dried alunite-residue. When she first started work in August 1975 there was no effective exhaust ventilation on the machine. A domestic fan was placed by her right shoulder to provide a stream of air to carry the dust away from her, but it tended to disseminate the dust locally. About eight months after starting this job she noticed the onset of dry cough and shortness of breath. Initially these symptoms came on during the morning at work and would subside during the evening at home, but they progressed and within three months they persisted throughout the day, improving only at weekends. She remained in her job for a total of 18 months, during which time her symptoms became more troublesome. After leaving the plant her symptoms improved, and her cough subsided completely after about three months. During the period of exposure she also complained of pain and morning stiffness in her metacarpophalangeal joints, wrists, elbows, and right knee. These symptoms also subsided within three months of cessation of exposure. Additionally, exposure was associated with general malaise, headache, and anorexia. Corticosteroid treatment with prednisone started after an open lung biopsy in March 1977, two months after cessation of exposure, was stopped in October 1979. At her worst she was persistently short of breath and coughing at rest. Currently she notices dyspnoea walking up hills or stairs but can keep up with others of her own age walking on level ground at an ordinary pace.

Physical examination throughout her period of observation showed the presence of coarse crackles in the mid and lower zones of her lungs bilaterally. There has been no finger clubbing or cyanosis. Her chest radiograph was normal in August 1976, three

Table 2 Pulmonary function tests of patient-January 1979

\begin{tabular}{|c|c|c|c|c|}
\hline & Predicted & Feb 1978 & Feb 1979 & Nov 1979 \\
\hline $\mathrm{FEV}_{1}(\mathrm{l})$ & $2 \cdot 4$ & $2 \cdot 0$ & $2 \cdot 0$ & $1 \cdot 7$ \\
\hline VC (1) & $2 \cdot 9$ & $2 \cdot 3$ & $2 \cdot 3$ & $2 \cdot 1$ \\
\hline TLC (l) & $4 \cdot 6$ & $4 \cdot 3$ & $4 \cdot 1$ & 3.9 \\
\hline $\mathrm{TL}_{\mathrm{L}}(\mathrm{mmol} / \mathrm{min} / \mathrm{kPa})$ & $8 \cdot 1$ & $3 \cdot 9$ & $4 \cdot 7$ & $5 \cdot 0$ \\
\hline \multicolumn{5}{|l|}{$\mathrm{T}_{\mathrm{L}} / \mathrm{V}_{\mathrm{A}}(\mathrm{mmol} / \mathrm{min} /$} \\
\hline $\mathrm{kPa} / \mathrm{l})$ & $1 \cdot 8$ & $1 \cdot 5$ & $1 \cdot 3$ & $1 \cdot 5$ \\
\hline$C_{L}(1 / k P a)$ & $2 \cdot 1$ & - & 0.90 & - \\
\hline$P L \max (k P a)$ & $2 \cdot 98$ & 一 & $8 \cdot 37$ & 一 \\
\hline
\end{tabular}




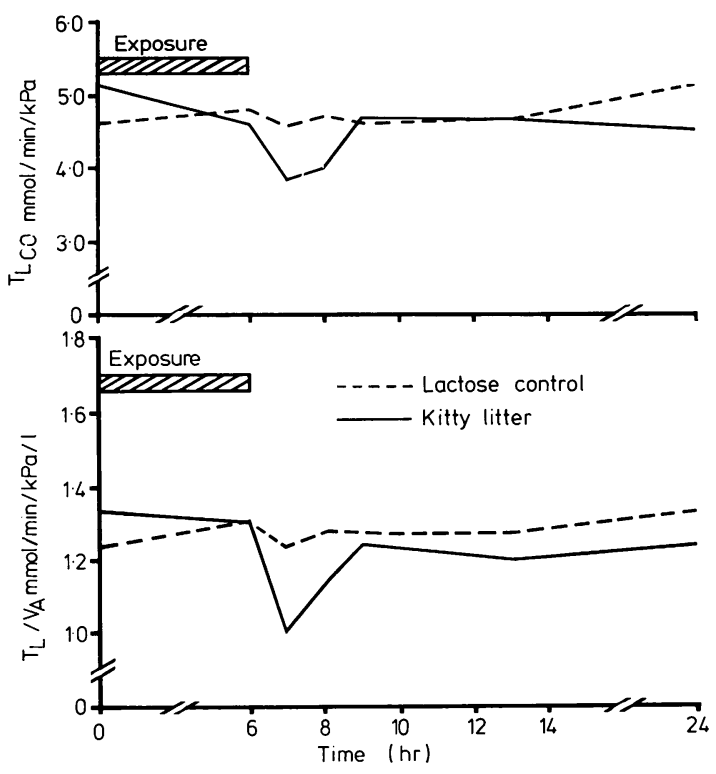

Fig 3 (a) Response of $T_{\mathrm{L}}$ to challenge with alunite-residue (continuous line) and control (lactose powder). (b) Response of $T_{\mathrm{L}} / V_{\mathrm{A}}$ to challenge with alunite-residue (continuous line) and control (lactose powder).

months after the onset of symptoms (fig 1) but showed diffuse small irregular opacities throughout both lung fields at the time of her presentation in March 1977 (fig 2). Pulmonary function tests in February 1978 and subsequently have shown a decrease in TL and TL/VA and abnormal transpulmonary pressure-lung volume relationships (table 2). There has been no change in $T L$ or $T L / V_{A}$ since February 1978.

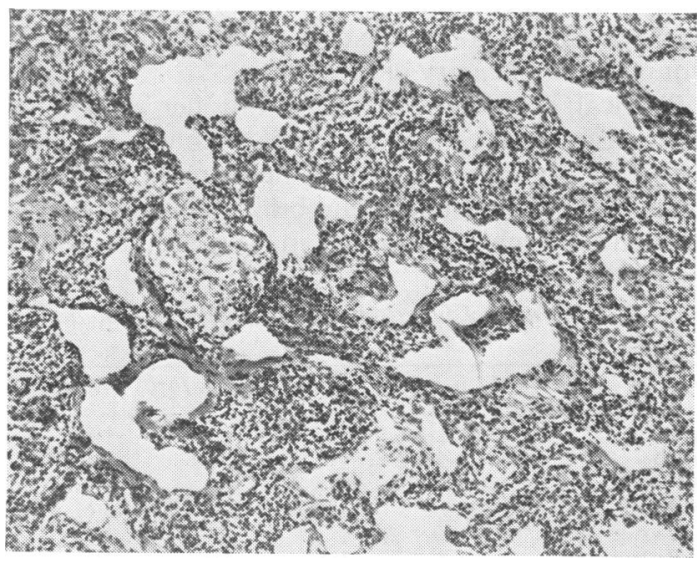

Fig 4 Histology of presenting case from open lung biopsy. (Haematoxylin and eosin $\times 100$.)
Quantitative serum protein electrophoresis showed a moderately raised gammaglobulin level of $22 \mathrm{~g} / \mathrm{l}$ (normal 9-16 g/l). Results of tests for rheumatoid factor using sensitised sheep red cells (Rheumaton, Hyland Laboratory) and Latex particles (Latex fixation test, Denver Laboratory) and for antinuclear factor were negative. Tests for cell-mediated immunity showed no response to intradermal injection of purified protein derivative or candida but a strong response to Varidase (streptokinase/streptodornase). Serum complement fractions were normal. Precipitins to antigens of Aspergillus sp and birds were negative by agar gel diffusion. Barium swallow was normal. A six-hour provocation test with nonquantitated exposure to the dust of powdered lactose as control material produced no change in $\mathrm{FEV}_{1}$, FVC, $T_{L}$, or TL/VA. Similar respiratory provocation with the dust of alunite-residue on the next day produced no effect on $\mathrm{FEV}_{1}$ or FVC, but a $20 \%$ reduction in $T_{L}$ and $T_{L} / V_{A}$ (fig 3 ).

Histology from open lung biopsy in March 1977 showed interstitial infiltration with small round cells, variable fibrosis, and scattered granulomas. The alveoli were distorted and the granulomas were moderately well formed with multinucleate giant cells and epithelioid histiocytes (fig 4). One hilar lymph node was obtained and showed reactive changes only. $X$-ray microanalysis of the pulmonary tissue showed the presence of aluminium.

In summary there was a clear temporal relation between the onset and remission of her symptoms and exposure to alunite-residue in the work place. Functional and radiographic evidence of pulmonary fibrosis was confirmed by histology, the interest being in the presence of granulomas within the lung. Since starting corticosteroids in April 1977 there has been no further deterioration in pulmonary function. Steroids were withdrawn in October 1979.

\section{Results of work force study}

The average age of the subjects was $29 \cdot 1$ years (range 15.1-52 1). Age was correlated with duration of employment $(r=0.77)$ and severity of exposure $(r=$ 0.59 ) in that the older subjects stayed in employment longer and were assigned to the more dusty job of filling bags with alunite-residue on the bagging machine. Overall, the group was comparable to predicted levels of FEV, VC, and TLC (tables 3 and 4). $T L$ and $T L / V_{A}$ were less than predicted.

The $\mathrm{TL} \%$ predicted of smokers and ex-smokers $(86.0 \%)$ was similar to that of non-smokers $(85.3 \%)$ but TL/VA \% predicted tended to be lower in smokers and ex-smokers $(85.3 \%)$ than non-smokers $(87.8 \%)$. Smokers were not disproportionately represented in the group with greater total dust exposure: mean 
Table 3 Table of pulmonary function tests for all subjects

\begin{tabular}{|c|c|c|c|c|c|c|c|c|c|c|}
\hline Subject & $\begin{array}{l}\text { Age } \\
(y r)\end{array}$ & $\begin{array}{l}\text { Height } \\
(\mathrm{cm})\end{array}$ & $\begin{array}{l}\text { TLC litre } \\
\text { (pred) }\end{array}$ & $\begin{array}{l}\text { VC litre } \\
\text { (pred) }\end{array}$ & $\begin{array}{l}\text { FEV } V_{1} \text { litre } \\
\text { (pred) }\end{array}$ & $\begin{array}{l}\text { FVC litre } \\
\text { (pred) }\end{array}$ & $\begin{array}{l}F E V_{1} / F V C \% \\
(\text { pred })\end{array}$ & $\begin{array}{l}T \mathrm{~L} \\
(\mathrm{mmol} / \mathrm{min} / \mathrm{kPa})\end{array}$ & $\begin{array}{l}T \mathbf{L} / V_{A} \\
(\mathrm{mmol} / \mathrm{min} / \mathrm{kPa} / \mathrm{l})\end{array}$ & $\begin{array}{l}\text { Total } \\
\text { exposure } \\
\text { ( } \Sigma \text { Grade } \times \\
\text { months) }\end{array}$ \\
\hline \multicolumn{11}{|l|}{ Men } \\
\hline $1 *$ & 18 & $175 \cdot 9$ & $6 \cdot 5(6 \cdot 8)$ & $4 \cdot 8(5 \cdot 2)$ & $4 \cdot 0(4 \cdot 4)$ & $4 \cdot 6(5 \cdot 2)$ & $86 \cdot 7(85 \cdot 1)$ & $10 \cdot 35(12.08)$ & $1.64(1.97)$ & 3 \\
\hline 2 & 29 & 182.9 & $8 \cdot 3(7 \cdot 4)$ & $5 \cdot 6(5 \cdot 3)$ & $4 \cdot 7(4 \cdot 3)$ & $5 \cdot 4(5 \cdot 3)$ & $86 \cdot 1(81 \cdot 0)$ & $11 \cdot 72(12 \cdot 11)$ & $1.54(1.82)$ & 36 \\
\hline 3* & 18 & $181 \cdot 0$ & $6 \cdot 9(7 \cdot 2)$ & $4 \cdot 1(5 \cdot 4)$ & $4 \cdot 2(4 \cdot 6)$ & $5.0(5 \cdot 4)$ & $83.4(85 \cdot 1)$ & $10.42(12.63)$ & $1.61(1.97)$ & 6 \\
\hline 4* & 17 & $170 \cdot 8$ & $6 \cdot 2(6 \cdot 3)$ & $4 \cdot 4(4 \cdot 9)$ & $4 \cdot 0(4 \cdot 2)$ & $4 \cdot 3(4 \cdot 9)$ & $92 \cdot 7(85 \cdot 5)$ & $9 \cdot 50(11.59)$ & $1.54(1.98)$ & 2 \\
\hline $5^{*}$ & 16 & $162 \cdot 6$ & $4 \cdot 8(5 \cdot 6)$ & $4 \cdot 0(4 \cdot 5)$ & $3 \cdot 2(4 \cdot 0)$ & $3 \cdot 8(4 \cdot 5)$ & $84.8(85.8)$ & $8.53(10.76)$ & $1.67(1.99)$ & 2 \\
\hline $6^{*}$ & 19 & $183 \cdot 5$ & $7 \cdot 7(7 \cdot 4)$ & $5 \cdot 1(5 \cdot 5)$ & $5 \cdot 1(4 \cdot 6)$ & $5 \cdot 8(5 \cdot 5)$ & $87 \cdot 7(84 \cdot 7)$ & $9.01(12.84)$ & $1 \cdot 17(1.95)$ & 48 \\
\hline $7+$ & 31 & $181 \cdot 6$ & $8 \cdot 7(7 \cdot 3)$ & $6.0(5 \cdot 2)$ & $5 \cdot 3(4 \cdot 2)$ & $6 \cdot 5(5 \cdot 2)$ & $82.9(80.2)$ & $14.21(11 \cdot 83)$ & $1.74(1.80)$ & 30 \\
\hline 8 & 15 & $172 \cdot 1$ & $4.9(5 \cdot 7)$ & $4 \cdot 0(4 \cdot 4)$ & $3.5(3.8)$ & $3.8(4.4)$ & $91.8(85.6)$ & $7.93(11.86)$ & $1.64(2.00)$ & 6 \\
\hline 9* & 18 & 166.4 & $5 \cdot 5(5 \cdot 9)$ & $4 \cdot 0(4 \cdot 7)$ & $4 \cdot 1(4 \cdot 1)$ & $4 \cdot 3(4 \cdot 7)$ & $96 \cdot 0(85 \cdot 1)$ & $8.34(11.04)$ & $1.37(1.97)$ & 24 \\
\hline 10 & 23 & $192 \cdot 4$ & $7 \cdot 6(8 \cdot 2)$ & $5.4(5.9)$ & $4 \cdot 6(4 \cdot 8)$ & $5.6(5.9)$ & $82 \cdot 5(83 \cdot 2)$ & $14 \cdot 36(13.54)$ & $1.97(1.90)$ & 24 \\
\hline $11^{*}$ & 17 & $179 \cdot 7$ & $7 \cdot 2(7 \cdot 1)$ & $5 \cdot 2(5 \cdot 4)$ & $4 \cdot 8(4 \cdot 6)$ & $5.4(5.4)$ & $89 \cdot 1(85 \cdot 5)$ & $9.46(12 \cdot 56)$ & $1.77(1.98)$ & 10 \\
\hline $12 *+$ & 41 & $161 \cdot 9$ & $6 \cdot 1(5 \cdot 5)$ & $4 \cdot 3(3.9)$ & $3.4(3 \cdot 2)$ & $4 \cdot 2(3 \cdot 9)$ & $80.9(76.5)$ & $7.47(9.01)$ & $1 \cdot 20(1.67)$ & 144 \\
\hline $\begin{array}{l}13 \dagger \\
\text { Women }\end{array}$ & 29 & $167 \cdot 6$ & $6 \cdot 7(6 \cdot 0)$ & $4 \cdot 9(4 \cdot 5)$ & $4 \cdot 3(3 \cdot 8)$ & $4 \cdot 9(4 \cdot 5)$ & $86 \cdot 1(81 \cdot 0)$ & $13.07(10.43)$ & $2 \cdot 11(1 \cdot 82)$ & 8 \\
\hline 15 & 36 & $160 \cdot 7$ & $4 \cdot 7(4 \cdot 9)$ & $3 \cdot 1(3 \cdot 1)$ & $2 \cdot 5(2 \cdot 6)$ & $3 \cdot 2(3 \cdot 1)$ & $79 \cdot 2(82 \cdot 7)$ & $7 \cdot 31(8.58)$ & $1.64(1.82)$ & 6 \\
\hline 16 & 50 & $158 \cdot 8$ & $5 \cdot 5(4 \cdot 5)$ & $3 \cdot 7(2 \cdot 7)$ & $2 \cdot 6(2 \cdot 3)$ & $3.4(2 \cdot 7)$ & $76 \cdot 3(79 \cdot 0)$ & $7.68(7.69)$ & $1 \cdot 61(1 \cdot 72)$ & 72 \\
\hline $17+ \pm$ & 52 & $153 \cdot 0$ & $4 \cdot 8(4 \cdot 1)$ & $2 \cdot 3(2 \cdot 4)$ & $2 \cdot 3(2 \cdot 1)$ & $2 \cdot 8(2 \cdot 4)$ & $82 \cdot 2(78 \cdot 5)$ & $4.85(7 \cdot 16)$ & $1 \cdot 17(1 \cdot 71)$ & 126 \\
\hline
\end{tabular}

* = Smoker.

$\dagger=$ Ex-smoker.

$\ddagger=$ Abnormal chest radiograph.

Table 4 Mean values of pulmonary function and percentage of predicted for all subjects

\begin{tabular}{lcc}
\hline & Mean $(S D)$ & $\%$ Predicted $(S D)$ \\
\hline FEV $_{1}$ & $3.80(1.01) 1$ & $101.0(12.0)$ \\
VC $_{\text {FEV }} /$ FVC & $4.31(1.06) 1$ & $97.4(14.7)$ \\
TLC & $6.4(5.0) \%$ & $103.3(4.5)$ \\
TL & $9.34(1.37) 1$ & $101.8(11.7)$ \\
TL/VA & $1.57(0.26) \mathrm{mmol} / \mathrm{min} / \mathrm{kPa} / \mathrm{l}$ & $85.8(18.6)$ \\
\hline
\end{tabular}

total exposure for smokers and ex-smokers was $36 \cdot 6$ exposure-months, and for non-smokers 33.0 exposure-months.

There was no relation between grade of dyspnoea or the presence of cough and sputum, and pulmonary function. Nor was there any difference in pulmonary function between the six subjects who stated that exposure to the dust of alunite-residue had affected their chests and those who considered it had not or between the five subjects who had ever had arthritis and those who had not.

The mean $\mathrm{TL} \%$ predicted for the whole group was 85.8 and the mean $\mathrm{TL}_{L} / \mathrm{VA}_{\mathrm{A}} \%$ predicted was 83.8 . Two subjects together with the index subject showed small irregular opacities on chest radiography. These three subjects had a significantly greater mean total exposure (108 exposure-months) and a tendency to lower mean TL $\%$ predicted $(69 \cdot 2)$ and $\mathrm{TL} / \mathrm{VA}_{\mathrm{A}} \%$ predicted $(71 \cdot 1)$ than the 14 subjects with normal chest radiographs (mean total exposure 20 exposure-months $(p<0.001), \mathrm{TL}_{\mathrm{L}} \%$ predicted $89.4 \%(p=0 \cdot 10)$, and TL/VA $\%$ predicted $86.6 \%$ $(p=0 \cdot 10)$. None of these subjects had previous exposure to hazardous dusts, and no recent chest radiographs were available for the two with abnormal radiographs who had no symptoms of respiratory disease.

The TL/VA \% predicted tended to correlate with the measurement of total dust exposure $(r=-0.40$ $p=0 \cdot 10$ ) (fig 5 ). $T_{L} \%$ predicted showed less tendency to correlate with total dust exposure $(r=$ $-0 \cdot 23)$.

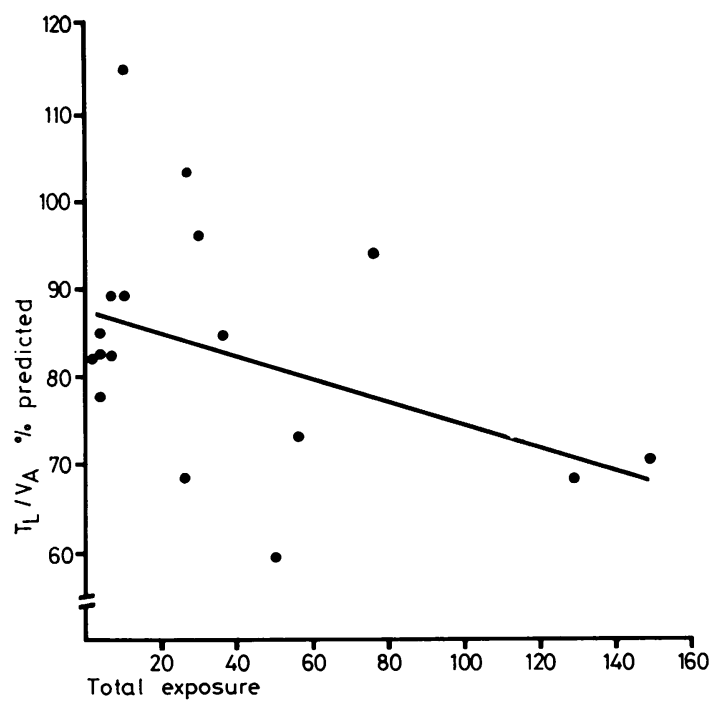

Fig 5 Relation between total exposure to alunite-residue (sum of the products of grade of each exposure period and duration of each exposure period in months) and $T_{\mathrm{L}} / V_{\mathrm{A}} \%$ predicted. $n=17 r=0.40 p=0 \cdot 10$. 


\section{Discussion}

Several problems that were encountered in interpreting this study arise from the small size of the exposed population, the possible confounding effect of smoking, and the association between age and total exposure. We have had to compare our data with external "predicted normal" values rather than carry out multivariate analysis or internal standardisation of the results. Nevertheless, the data from the initial case and from the work force suggest a relation between exposure to the dust of aluniteresidue and impairment of the rate of gas transfer of the lung: the mean values of $T_{L}$ and $T_{L} / V_{A}$ of the group were less than predicted, there was a tendency to an inverse relation between $\mathrm{TL} / \mathrm{VA}_{\mathrm{A}} \%$ predicted and magnitude of exposure to alunite-residue, and subjects with abnormal radiographs were among the four with the highest exposures. The closer relation between $T_{L} / V_{A} \%$ predicted and total exposure than between $T_{L} \%$ predicted or lung volumes and total exposure suggests that the pulmonary reaction had a greater effect on the rate of gas transfer than on the effective alveolar volume.

The physiological and radiographic findings of the group are consistent with the pathological appearance of the lung biopsy specimen. We are planning to investigate the mechanism by which aluniteresidue may produce pulmonary fibrosis. Immunological mechanisms were suggested by the time course of the transfer-factor response to bronchial challenge and the presence of granulomas in the lung, but they appear unlikely because of the inorganic nature of the material. The precedent for such a reaction, however, has been long recognised in beryllium $^{16}$ and tungsten carbide, ${ }^{17} 18$ and it is known that, experimentally, zirconium ${ }^{19}$ may also produce pulmonary fibrosis with granulomas, possibly by a foreign body reaction or by combining with protein constituents of the lungs to form an antigen. The presence of systemic symptoms of malaise and arthritis is somewhat against the possibility of a purely local foreign body reaction: challenge studies in our patient resulted in a recrudescence of systemic as well as respiratory symptoms, and change in TL and TL/VA. We have no other evidence, however, to suggest multiple organ involvement. We are aware that clays (palygorscite) ${ }^{20}$ may have a fibrous form, but our material contains no fibres on electron microscopy.

Our study suggests that a silicate of aluminium may be responsible for pulmonary fibrosis, and industrial users of this type of material should be vigilant. It suggests that the classification of such materials as nuisance dusts should be reviewed.

We thank Dr K E Finucane for his help in conducting this study and the preparation of this report, Dr $\mathrm{R}$ Warren for providing the slide of the lung biopsy specirnen, and $\operatorname{Dr} \mathbf{J}$ Pappadimitriou for $x$-ray microanalysis of the lung tissue. Figures were provided by the department of medical illustrations at the Queen Elizabeth Medical Centre and secretarial help by Mrs C Mole, Miss J Tyers, and Mrs C Gellé.

\section{References}

1 Mitchell J, Manning GB, Molyneux M, Lane RE. Pulmonary fibrosis in workers exposed to finely powdered aluminium. Br $J$ Ind Med 1961;18:10-20.

${ }^{2}$ Shaver CG, Riddell AR. Lung changes associated with the manufacture of alumina abrasives. J Ind Hyg Toxic 1947;29:145-57.

${ }^{3}$ Midttun $\mathrm{O}$. Bronchial asthma in the aluminium industry. Acta Allergol 1960;15:208-21.

4 Jötten KW, Eickhoff W. Lungenveranderungen durch sillimanitstaub. Archiv für Gewerbepathologie und Gewerbehygiene 1944;12:223-32.

${ }^{5}$ International Labour Office. Permissible levels of toxic substances in the working environment. Occupational Safety and Health Series No 20. Geneva: ILO, 1970.

- American Conference of Governmental Industrial Hygienists. Threshold limit values for chemical substances in workroom air adopted by $A C G I H$ for 1976. Cincinnati, Ohio: ACGIH, 1976.

${ }^{7}$ Health and Safety Executive. Threshold limit values for 1977. L.ondon: HMSO, 1977.

${ }^{8}$ National Health and Medical Research Council. Atmospheric contaminants. Canberra: Australian Government Publishing Service, 1975.

${ }^{9}$ Medical Research Council Committee on the Aetiology of Chronic Bronchitis. Definition and classification of chronic bronchitis for clinical and epidemiological purposes. Lancet $1965 ; \mathrm{i}: 775-9$.

10 Ogilvie CM, Forster RE, Blackmore WS, Morton JW. A standardised breath-holding technique for the clinical measurement of the diffusing capacity of the lung for carbon monoxide. $J$ Clin Invest 1975;36:1-12.

11 Finucane KE, Mead J, Peterson N. Estimation of alveolar pressure during forced oscillation of the respiratory system. J Appl Physiol 1975;38:531-7.

12 Dubois AB, Botelho SY, Bedell GN, Marshall R, Comroe JH. A rapid plethysmographic method for measuring thoracic gas volume: a comparison with nitrogen washout method for measuring functional residual capacity in normal subjects. J Clin Invest $1956 ; 35: 322-6$.

13 Milic Emili J, Mead J, Turner JM, Glauser EM. Improved technique for estimating pleural pressure from esophageal balloons. J Appl Physiol 1964;19:207-11.

14 Cherniack RM, Raber MB. Normal standards for ventilatory function using an automated wedge spirometer. Am Rev Resp Dis 1972;106:38-46.

15 Cotes JE. Lung function, assessment and application in medicine. 3rd ed. Oxford: Oxford Scientific Publications, 1975.

16 Kanarek DJ, Wainer RA, Chamberlain RI, Weber AL, Kazemi H. Respiratory illness in a population exposed to beryllium. Am Rev Resp Dis 1973;108:1295-1302.

17 Coates EO, Watson JHL. Diffuse interstitial lung disease in tungsten carbide workers. Ann Int Med 1971;75:709-16.

${ }^{18}$ Coates EO, Watson JHL. Pathology of the lung in tungsten carbide workers using light and electron microscopy. J Occup Med 1973;15:280-6.

19 Prior J, Cronk GA, Ziegler DD. Pathological changes associated with the inhalation of sodium zirconium lactate. Arch Env Health 1960;1:297-301.

${ }^{20}$ International Agency for Research in Cancer. Asbestos. IARC Monographs on the Evaluation of Carcinogenic Risk of Chemicals to Man. Vol 14. Lyon: IARC, 1977. 